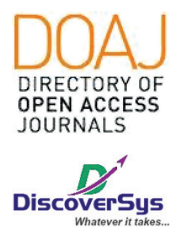

Published by DiscoverSys

\title{
Prevalensi gambaran faktor risiko penyakit jantung koroner pada pasien diabetes melitus tipe-2 di RSUP Sanglah Denpasar periode 2015
}

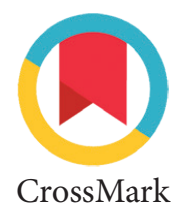

\author{
Ni Putu Widya Nandasari, ${ }^{1 *}$ Desak Gde Diah Dharma Santhi, ${ }^{2}$ \\ I Wayan Putu Sutirta Yasa ${ }^{2}$
}

CrossMark

\section{ABSTRACT}

Introduction: The main causes of mortality and morbidity in patients with Type-2 Diabetes Melitus (T2DM) is coronary heart disease. This study aims to describe various risk factors for coronary heart disease, modified and unmodified included among patients with T2DM in Sanglah General Hospital, within 2015.

Method: The research uses descriptive cross-sectional design with total sampling technique has been used as sampling method. Data was taken from patients's medical record within the period of January to December 2015. It was processed using SPSS 21 and presented in a frequency distribution table and crosstabulation based on risk factors. Around 48 samples which met the criteria were included in this study.

Result: It was obtained that the prevalence of the unmodified risk factors of CHD in T2DM were male gender (87.5\%) and aged $\geq 45$ years old (95.8\%). The modified factors are fasting blood glucose $\geq 126 \mathrm{mg} / \mathrm{dL}\left(83.3 \%\right.$ ), body mass index $\geq 25 \mathrm{~kg} / \mathrm{m}^{2}(64.6 \%)$, random blood glucose $\geq 200 \mathrm{mg} / \mathrm{dL}(58.3 \%), \mathrm{HDL} \leq 45 \mathrm{mg} / \mathrm{dL}(41.7 \%)$, triglycerides $\geq 150 \mathrm{mg} / \mathrm{dL}$ (22.9\%), blood pressure $\geq 140 / 90 \mathrm{mmHg}$ (22.9\%), total cholesterol $\geq 200 \mathrm{mg} / \mathrm{dL}$ (22.9\%), and LDL $\geq 160 \mathrm{~mm} / \mathrm{dL}$ (8.3\%).

Conclusion: It can be concluded that men with age $\geq 45$ years, fasting blood glucose, body mass index, and uncontrolled random blood glucose are risk factor for CHD in T2DM in Sanglah Hospital. Therefore, monitoring of blood sugar levels and body mass index in patients with T2DM are necessary to prevent CHD.
'Program Studi Pendidikan Dokter Fakultas Kedokteran Universitas Udayana

${ }^{2}$ Bagian/KSM Patologi Klinik RSUP Sanglah Denpasar

${ }^{*}$ Correspondence to: Ni Putu Widya Nandasari, Program Studi Pendidikan Dokter Fakultas Kedokteran Universitas Udayana nandasari29@gmail.com

Diterima: $13-09-2019$

Disetujui: $10-07-2020$

Diterbitkan: 01-08-2020

Keywords: type 2 diabetes mellitus, coronary heart disease, risk factors. Cite This Article: Nandasari, N.P.W., Santhi, D.G.D.D., Yasa, I.W.P.S. 2020. Prevalensi gambaran faktor risiko penyakit jantung koroner pada pasien diabetes melitus tipe-2 di RSUP Sanglah Denpasar periode 2015. Intisari Sains Medis 11(2): 484-488. D0I: 10.15562/ism.v11i2.616

\section{ABSTRAK}

Latar Belakang: Penyebab mortalitas dan morbiditas utama pada pasien Diabetes Melitus Tipe-2 (DMT2) adalah penyakit jantung coroner (PJK). Penelitian ini bertujuan untuk mengetahui gambaran berbagai faktor risiko penyakit jantung koroner yang tidak dapat diubah dan dapat diubah pada penderita DMT2 di Rumah Sakit Umum Pusat Sanglah periode 2015. Metode: Penelitian menggunakan desain deskriptif cross-sectional, dan pengambilan sampel dilakukan dengan teknik total sampling. Data diambil berdasarkan rekam medis pasien periode Januari - Desember 2015. Kemudian data diolah menggunakan SPSS 21, dan disajikan dalam bentuk tabel distribusi frekuensi dan crosstabulation berdasarkan faktor risiko.

Hasil: Didapatkan sebanyak 48 sampel penelitian yang memenuhi kriteria dan dapat digunakan dalam studi ini, diperoleh prevalensi gambaran faktor risiko PJK pada DMT2 yang tidak dapat diubah adalah jenis kelamin laki-laki $(87,5 \%)$ dan usia $\geq 45$ tahun $(95,8 \%)$. Faktor yang dapat diubah seperti gula darah puasa $\geq 126 \mathrm{mg} / \mathrm{dL}(83,3 \%)$, indeks masa tubuh $\geq 25 \mathrm{~kg} / \mathrm{m}^{2}(64,6 \%)$, gula darah sewaktu $\geq 200 \mathrm{mg} / \mathrm{dL}$ (58,3\%), HDL $\leq 45 \mathrm{mg} / \mathrm{dL}$ (41,7\%), trigliserida $\geq 150 \mathrm{mg} / \mathrm{dL}(22,9 \%)$, tekanan darah $\geq 140 / 90 \mathrm{mmHg}$ (22,9\%), kolesterol total $\geq 200 \mathrm{mg} / \mathrm{dL}(22,9 \%)$, dan LDL $\geq 160 \mathrm{~mm} / \mathrm{dL}(8,3 \%)$.

Conclusion: Laki-laki dengan usia $\geq 45$ tahun, gula darah puasa, indeks masa tubuh, dan gula darah sewaktu yang tidak terkontrol merupakan faktor risiko untuk terjadinya PJK pada DMT2 di RSUP Sanglah. Sehingga diperlukan pengawasan kadar gula darah dan indeks masa tubuh pada pasien DMT2 agar tidak terjadi PJK.

Kata kunci: diabetes melitus tipe 2, penyakit jantung koroner, faktor risiko.

Cite Pasal Ini: Nandasari, N.P.W., Santhi, D.G.D.D., Yasa, I.W.P.S. 2020. Prevalensi gambaran faktor risiko penyakit jantung koroner pada pasien diabetes melitus tipe-2 di RSUP Sanglah Denpasar periode 2015. Intisari Sains Medis 11(2): 484-488. D0I: 10.15562/ism.v11i2.616

\section{PENDAHULUAN}

Diabetes Melitus Tipe 2 (DMT2) ini membentuk 90 95\% dari semua kasus diabetes, DMT2 merupakan penyakit kelainan metabolik yang ditandai dengan hiperglikemia serta diakibatkan oleh kelainan sekresi insulin, kerja insulin maupun keduanya. Tipe ini dikenal dengan noninsulin dependent Diabetes Mellitus 
(NIDDM). ${ }^{1}$ Pada diabetes ini terjadi resistensi insulin dan disfungsi sel $\beta$ yang menyebabkan terjadinya defisiensi insulin relatif. Kegemukan atau obesitas sering berhubungan dengan kondisi ini. ${ }^{2}$ International Diabetes Federation (IDF) menyebutkan bahwa prevalensi DMT2 di dunia adalah 1,9\% dan merupakan penyebab kematian urutan ketujuh di dunia. ${ }^{3}$ Hasil Riset Kesehatan Dasar pada tahun 2008, menunjukan prevalensi DMT2 di Indonesia membesar sampai 57\%. ${ }^{4}$ Badan Pusat Statistik Indonesia juga menyampaikan pada tahun 2003 diperkirakan terdapat penderita diabetes sejumlah 8,2 juta jiwa di perkotaan dan 5,5 juta jiwa di daerah pedalaman. Berdasarkan data ini diperkirakan pada tahun 2030 di Indonesia, penderita diabetes menjadi sejumlah 12 juta di daerah perkotaan dan 8,1 juta di daerah pedalaman. ${ }^{5}$

DMT2 merupakan penyakit yang dapat menimbulkan komplikasi jangka panjang berupa adanya gangguan vaskular, tak terkecuali gangguan pada arteri koroner jantung. Berdasarkan data, sekitar 75\% pasien dengan DMT2 memikiki mortalitas akibat adanya penyakit kardiovaskular termasuk Penyakit Jantung Koroner (PJK). ${ }^{6}$ DMT2 sendiri sudah dianggap sebagai faktor risiko terjadinya PJK dengan $70 \%$ pasien DMT2 dengan usia $>65$ tahun menderita PJK yang berkaitan dengan morbiditas dan mortalitas mereka. ${ }^{7}$ Sebuah studi meta analisa terbaru menunjukkan bahwa PJK menjangkit 32,3\% dari populasi DMT2 di dunia dengan 29,1\% nya terbukti memiliki atherosclerosis, dan $14,9 \%$ nya mengalami gagal jantung. Sebanyak 10\% dari mereka pernah mengalami episode serangan yang menyebabkan infark miokard. PJK merupakan penyebab dari 9,9\% kematian pasien DMT2 di dunia. ${ }^{8}$ Adanya PJK dengan kondisi DMT2 juga mempengaruhi pendekatan terapi dimana tindakan revaskularisasi cenderung dilakukan dengan pembedahan terbuka dibandingkan dengan pendekatan perkutan. Hal ini tentunya berdampak pada beban ekonomi, morbiditas dan mortalitas pada penyakit itu sendiri. ${ }^{6}$ Oleh karena hal ini, peneliti merasa perlu untuk melakukan penyeledikan terhadap faktor risiko yang meungkin menyebabkan perkembangan PJK pada pasien DMT2. Dengan diketahuinya faktor risiko, diharapkan ditemukan strategi yang tepat untuk mencegah kejadian PJK pada pasien DMT2 sehingga morbiditas dan mortalitas mereka dapat dikurangi.

\section{METODE}

Penelitian ini menggunakan rancangan penelitian observasional deskriptif dengan pendekatan potong lintang. Penelitian dilakukan di RSUP Sanglah bulan Maret 2016 - Agustus 2016. Sampel diambil dengan metode total sampling dimana pasien DMT2 dengan komplikasi PJK di RSUP Sanglah pada periode penelitian diikutsertakan dalam penelitian hingga mencapai kebutuhan. Subjek dengan data rekam medis yang tidak lengkap di ekslusi dari penelitian. Data yang diambil berupa data sekunder yang berasal dari catatan rekam medis pasien, dengan variabel yang diambil adalah jenis kelamin, usia, tekanan darah, profil lipid seperti kolesterol total, high density lipoprotein (HDL), low density lipoprotein (LDL), dan trigliserida, gula darah puasa (GDP), dan gula darah sewaktu (GDS), dan nilai indeks massa tubuh (IMT).

\section{HASIL}

Subjek yang memenuhi kriteria inklusi dan ekslusi sehingga dapat diikutsertakan dalam studi

\section{Tabel 1 Distribusi Karakteristik Pasien DMT2 yang mengalami komplikasi PJK di RSUP Sanglah Pada Periode 2015}

\begin{tabular}{lcc}
\hline Variabel & $\begin{array}{c}\text { Frekuensi } \\
(\mathrm{n}=48)\end{array}$ & $\begin{array}{c}\text { Presentase } \\
(\%)\end{array}$ \\
\hline
\end{tabular}

Umur (Tahun)

$<45$

2

4,2

$>45$

46

Jenis Kelamin

Laki-laki

42

87,5

Perempuan

6

Tekanan Darah

$<140 / 90 \mathrm{mmHg}$

$>140 / 90 \mathrm{mmHg}$

IMT

$<25 \mathrm{~kg} / \mathrm{m}^{2}$

$\geq 25 \mathrm{~kg} / \mathrm{m}^{2}$

Kadar Kolesterol Total

$<200$

$\geq 200$

11

Kadar LDL

$<160 \mathrm{mg} / \mathrm{dL}$

$\geq 160 \mathrm{mg} / \mathrm{dL}$

Kadar HDL

$$
<45
$$

$\geq 45$

Kadar Trigliserida

$<150$

$\geq 150$

Gula Darah Sewaktu

$$
<200 \mathrm{mg} / \mathrm{dL}
$$

$\geq 200 \mathrm{mg} / \mathrm{dL}$

\section{Gula Darah Puasa}

$$
\begin{aligned}
& <126 \mathrm{mg} / \mathrm{dL} \\
& \geq 126 \mathrm{mg} / \mathrm{dL}
\end{aligned}
$$$$
8
$$$$
16,7
$$$$
40
$$ 
berjumlah total 48 orang. Karakteristik sampel adalah didonminasi oleh orang yang berusia $>45$ tahun dengan persentase $95,8 \%$, lelaki dengan persentase $87,5 \%$, IMT $>25 \mathrm{~kg} / \mathrm{m}^{2}$ dengan presentase $64,6 \%$, kadar kolesterol $<200 \mathrm{mg} / \mathrm{dL}$ dengan persentase $77,1 \%$, kadar $\mathrm{LDL}<160 \mathrm{mg} / \mathrm{dL}$ dengan persentase 91,6\%, kadar HDL $>45 \mathrm{mg} / \mathrm{dL}$ dengan persentase $58,3 \%$, kadar trigliserida $<150 \mathrm{mg} / \mathrm{dL}$ dengan persentase $77,1 \%$, kadar gula darah sewaktu $>200 \mathrm{mg} / \mathrm{dL}$ dengan persentase 58,3\% dan kadar gula darah puasa $>126 \mathrm{mg} / \mathrm{dL}$ dengan persentase $83,3 \%$. Data selengkapnya dapat dilihat pada Tabel 1.

Tabulasi silang dilakukan untuk melihat karakteristik pasien DMT2 dengan komplikasi PJK berdasarkan jenis kelamin. Didapatkan bahwa tidak ada wanita yang memiliki kadar LDL $>160 \mathrm{mg} / \mathrm{dL}$.

\section{Tabel 2 Distribusi Karakteristik Pasien DMT2 yang mengalami komplikasi PJK di RSUP Sanglah Pada Periode 2015 Berdasarkan Jenis Kelamin}

\begin{tabular}{lll}
\hline \multirow{2}{*}{ Variabel } & \multicolumn{2}{c}{ Jenis Kelamin } \\
\cline { 2 - 3 } & Laki-Laki $(n, \%)$ & Perempuan $(n, \%)$ \\
\hline
\end{tabular}

Umur (Tahun)

$<45$

$>45$

Tekanan Darah

$<140 / 90 \mathrm{mmHg}$

$>140 / 90 \mathrm{mmHg}$

IMT

$<25 \mathrm{~kg} / \mathrm{m}^{2}$

$\geq 25 \mathrm{~kg} / \mathrm{m}^{2}$

Kadar Kolesterol Total

$$
<200
$$

$\geq 200$

Kadar LDL

$<160 \mathrm{mg} / \mathrm{dL}$

$\geq 160 \mathrm{mg} / \mathrm{dL}$

Kadar HDL

$$
<45
$$$$
\geq 45
$$

$1(2,4)$

$41(97,6)$

$33(78,6)$

$9(21,4)$

$16(38,1)$

$28(61,9)$

$33(78,6)$

$9(21,4)$

$38(90,5)$

$4(9,5)$

$18(42,9)$

$24(57,1)$

Kadar Trigliserida

$$
<150
$$$$
\geq 150
$$

$19(45,2)$

$23(54,8)$

$6(14,3)$

$36(85,7)$
$1(16,7)$

$5(83,3)$

$4(66,7)$

$2(33,3)$

$1(16,7)$

$5(83,3)$

$4(66,7)$

$2(33,3)$

$6(100,0)$

$0(0,0)$

$2(33,3)$

$4(66,7)$

$4(66,7)$

$2(33,3)$

$1(16,7)$

$5(83,3)$

$2(33,3)$

$4(66,7)$
Pada variabel lain, proporsi perempuan dan lelakinya hampir memiliki pola yang sama, misalnya, baik laki-laki dan perempuan memiliki proporsi dominan pada usia $>45$ tahun, tekanan darah $<140 / 90 \mathrm{mmHg}$, IMT $>25 \mathrm{~kg} / \mathrm{m}^{2}$, kolesterol total $<200 \mathrm{mg} / \mathrm{dL}$, kadar LDL < 160mg/dL, kadar HDL $>45 \mathrm{mg} / \mathrm{dL}$, kadar trigliserida $<150 \mathrm{mg} / \mathrm{dL}$, kadar gula darah sewaktu $>200 \mathrm{mg} / \mathrm{dL}$ dan kadar gula darah puasa $>126 \mathrm{mg} / \mathrm{dL}$. Karena tidak dilakukan analisa statistik lebih lanjut maka tidak dapat ditentukan apakah terdapat perbedaan yang signifikan antara kelompok lelaki dan perempuan. Data selengkapnya dapat dilihat pada Tabel 2.

\section{PEMBAHASAN}

DMT2 merupakan salah satu penyakit yang dapat menyebabkan kelainan pada arteri koroner. Sebuah studi yang dilakukan oleh Srinivisan dkk pada tahun 2013 menunjukkan bahwa terdapat korelasi yang signifikan antara resistensi insulin dengan kejadian PJK ( $r=0,303 ; p=0,009)$ dimana hal ini dapat menunjukkan adanya kaitan antara DMT2 dengan PJK. ${ }^{9}$ Berdasarkan American Heart Association (AHA), strategi prevensi PJK pada pasien DMT2 didasarkan pada faktor risiko yang berdasarkan berbagai Randomized Clinical Trial (RCT) terbukti meningkatkan tendensi terjadinya PJK pada pasien DMT2 diantaranya adalah tekanan darah $>130 / 80$, LDL > 100mg/dL, HbA1c > 7\%, dan merokok. ${ }^{6}$

Mekanisme yang mendasari terjadinya PJK pada pasien DMT2 dikaitkan pada adipositas visceral, resistensi insulin dan perubahan pada faktor sirkulasi. Atherogensis dimulai pada saat terjadi disfungsi sel endotel akibat adanya berbagai faktor yang menyebabkan injuri seperti dyslipidemia, hipertensi, diabetes, dan merokok yang dapat menginduksi deficit dari nitric oxide (NO) dan prostasiklin. Kemudian sel mononuklear seperti monosit dan limfosit T berikatan dengan endothelium yang dimediasi oleh molekul adeshi permukaan endotel seperti vascular cell adhesion molecul (VCAM), intercellular adhesion molecul (ICAM) dan E-Selectin. Monosit bermigrasi ke dalam ruang sub endotel, lalu matang menjadi residen makrofag dan mengambil lipid melalui reseptor scavenger seperti SR-A dan CD-36 da membentuk sel busa. Kemudian, sel otot polos bermigrasi ke permukaan dan membentuk cap fibrous dari lesi. Makrofak dan lemak melepaskan famili Matrix Metalloproteinase (MMP) yang menyebabkan rupturnya plak yang menyumbat arteri koroner dengan diameter yang lebih sempit menyebabkan terjadinya sindrom koroner akut. ${ }^{6,7}$

Berdasarkan karekteristik sampel dari studi ini, ditemukan bahwa pasien DMT2 dengan PJK lebih banyak lelaki dengan dominasi usia $>45$ tahun. 
Hal ini sesuai dengan studi yang sebelumnya dilakukan dimana dikatakan terdapat peningkatan risiko $20 \%$ di setiap penambahan usia. Ditemukan juga bahwa lelaki diabetes memiliki risiko 2,56 kali lebih besar untuk menderita PJK $(95 \% \mathrm{CI}=2,53-2,60)$, meskipun dalam hal mortalitas wanita dengan diabetes justru lebih berisiko $(\mathrm{HR}=3,50 ; 95 \% \mathrm{CI}=2,0-4,53) .{ }^{10}$

Dalam studi ini juga ditemukan dominasi pasien dengan IMT $>25 \mathrm{~kg} / \mathrm{m}^{2}$. Hal ini sesuai dengan studi sebelumnya dimana ditemukan bahwa $86 \%$ pasien DMT2 memiliki kadar IMT $>25 \mathrm{~kg} / \mathrm{m}^{2}$, dengan $52 \%$ didiagnosis obesitas (IMT $>30 \mathrm{~kg} / \mathrm{m}^{2}$ ) dan $8 \%$ menderita obesitas morbid $\left(>40 \mathrm{~kg} / \mathrm{m}^{2}\right)$. Studi tersebut juga menemukan kaitan antara obesitas pada pasien DMT2 dengan terjadinya dyslipidemia $(\mathrm{p}<0,001)$ dan hipertensi $(\mathrm{p}=0,04)$ yang dikaitkan dengan peningkatan risiko PJK. ${ }^{11}$

Dilihat dari profil lipidnya, pada studi ini justru kadar lipid sampel lebih banyak yang bernilai normal dibandingkan yang tinggi. Meskipun secara keseluruhan hanya sebagian kecil subjek pada studi ini yang mengalami dislipidemia, sebagian besar pasien memiliki kadar gula darah yang tinggi baik dalam waktu puasa maupun sewaktu. Tingginya gula darah dikaitkan dengan hubungan linear terhadap tingginya tingkat resistensi insulin pada pasien DMT2. Insulin dapat meningkatkan produksi NO dengan mengaktivasi NO sintese III pada endotel melalui jalur signaling PI3K/ Akt. Pada pasien dengan resistensi insulin, terjadi inhibisi selektif dari jalur PI3K/Akt pada vaskular yang menyebabkan disfungsi endotel sehingga meningkatkan interaksi sel endotel dengan leukosit. Hal ini akan berdampak pada peningkatan tonus vaskular dan tekanan darah yang juga akan memperparah injuri sel endotel. Viskositas darah pada pasien DMT2 yang relatif lebih tinggi akibat hiperglikemia, berkontribusi terhadap terjadinya statis protrombosis pada vaskular. Bersamaan, mekanisme tersebut menyebabkan pembentukan plak yang mengoklusi pembuluh darah. ${ }^{7}$ Selain itu, hiperglikemia juga dapat menimbulkan inflamasi dan stress oksidasi kronik akibat aktivasi berbagai mediator seperti IL-1 $\beta$, IL-6, TNF- $\alpha$ dan CRP dimana hal ini juga akan menyebabkan terjadinya injuri endotel. ${ }^{12}$

Dilihat berdasarkan jenis kelaminnya, tidak terdapat perbedaan mencolok antara jenis kelamin lelaki dan perempuan. Dominasi jumlah proporsi pada masing-masing variabel memiliki pola yang sama pada tiap jenis kelamin. Akan tetapi, perbedaan mencolok dapat dilihat dimana perempuan tidak ada yang memiliki kadar LDL yang tinggi. Hal ini sesuai dengan studi yang dilakukan oleh Zitnanova dkk. yang menemukan bahwa pada lelaki, cenderung terjadi peningkatan kadar LDL yang lebih besar dibandingkan dengan wanita $(\mathrm{p}<0,001)$. Fakta bahwa kadar LDL pada wanita cenderung lebih rendah juga mungkin menjelaskan bahwa risiko PJK pada pria dengan diabetes lebih tinggi..$^{13}$ Data dari sebuah studi besar yang dilakukan selama 7 tahun dan melibatkan 67395 subjek juga menemukan hasil yang serupa dimana pasien lelaki memiliki profil lipid yang cenderung lebih buruk dibandingkan dengan wanita dengan rerata LDL $110,7+38 \mathrm{mg} / \mathrm{dL}$ vs $100,2+16 \mathrm{mg} / \mathrm{dL}$ akan tetapi, selama 7 tahun wanita justru mengalami penurunan kadar LDL lebih rendah dengan laju penurunan $0,65 \mathrm{mg} / \mathrm{dL}$ dibandingkan dengan 1,01 pada pria..$^{14}$

Penelitian ini menggunakan titik potong variabel yang lebih tinggi untuk kriteria dislipdemia dibandingkan dengan anjuran dari AHA sehingga mungkin menyebabkan hasil yang cenderung nampak normal. Tidak dilakukan analisa statistik terhadap faktor risiko sehingga sulit ditentukan korelasi pada variabel tersebut terhadap kejadian PJK.

Keterbatasan dari penelitian ini yaitu penelitian ini merupakan studi deskriptif sehingga tidak melihat nilai kemaknaan serta koefisien korelasi dari variable terkait. Keterbatasan waktu serta akses rekam medis menyebabkan studi ini memiliki jumlah sampel yang sedikit. Perlu dilakukan studi lebih lanjut dengan jumlah sampel yang lebih representative terhadap populasi dan melihat korelasi antar variabel sebagai faktor risiko PJK pada pasien dengan DMT2.

\section{SIMPULAN}

Laki-laki dengan usia $\geq 45$ tahun, gula darah puasa, indeks masa tubuh, dan gula darah sewaktu yang tidak terkontrol merupakan faktor risiko untuk terjadinya PJK pada DMT2 di RSUP Sanglah. Sehingga diperlukan pengawasan kadar gula darah dan indeks masa tubuh pada pasien DMT2 agar tidak terjadi PJK.

\section{KONFLIK KEPENTINGAN}

Penulis menyatakan tidak terdapat konflik kepentingan terkait publikasi dari artikel ini.

\section{PENDANAAN}

Penelitian ini tidak mendapat hibah dana dari pemerintah maupun lembaga swasta lainnya.

\section{ETIKA DALAM PENELITIAN}

Penelitian ini telah disetujui oleh Komite Etik Fakultas Kedokteran Universitas Udayana/RSUP Sanglah Denpasar. 


\section{DAFTAR PUSTAKA}

1. American Diabetes Association (ADA). Standards of Medical Care in Diabetes-2019 abdridge for Primary Care Providers. Clinical Diabetes. 2019;37(1):11-34.

2. Gamayanti K, Ratnasari N, Bhargah A. Pola penggunaan insulin pada pasien diabetes mellitus tipe 2 di poli penyakit dalam RSU Negara Periode Juli - Agustus 2018. Intisari Sains Medis. 2018;9(3):68-73. DOI:10.15562/ism.v9i3.306

3. American Diabetes Association (ADA). Diagnosis and Classification of Diabetes Mellitus. Diabetes Care. 2011;33(Suppl 1):S62-S69.

4. Kirthi A, Yasmin A, Artha I, Bhargah A. Hipertensi sebagai prediktor kejadian kardiovaskular mayor pada pasien infark miokard akut pada tahun 2018 di RSUP Sanglah Denpasar, Bali-Indonesia. Intisari Sains Medis. 2019;10(3):530-536. DOI:10.15562/ism.v10i3.443

5. Artha IMJR, Bhargah A, Dharmawan NK, et al. High level of individual lipid profile and lipid ratio as a predictive marker of poor glycemic control in type- 2 diabetes mellitus. Vasc Health Risk Manag. 2019;15:149-157. doi:10.2147/VHRM.S209830

6. Naito R, Kasai T. Coronary artery disease in type 2 diabetes mellitus: recent treatmemt strategies and future perspective. World J Cardiol. 2015;7(3):119-124.

7. Martin I, Collantes C, Galindo A, Gomez F. Type 2 diabetes and cardiovascular disease: Have all risk factors the same strength. World J Diabetes. 2014;5(4):444-470.

8. Einarson T, Acs A, Ludwig C. Prevalence of cardiovascular disease in type 2 diabetes: a systematic literature review of scientific evidence from across the world in 2007-2017. Cardiovasc Diabetol. 2018;17:83-89.
9. Srinavasan M, et.al. Correlation of severity of coronary artery disease with insulin resistance. N Am J Med Sci. 2013;5(10):611-14

10. Bertolouchi M, Rocha V. Cardiovascular risk assessment in patients with diabetes. Diabetol Metab Syndr. 2017;9:25-32.

11. Dousi C, Cassom I, Farlane I, et al. Prevalence of obesity in type 2 diabetes in secondary care: association with cardiovascular risk factors. Postgrad Med J. 2006; 82(96):280-4.

12. De Rosa S, Arcidiacono B, Chiefari E, Brunetti A, Indolfi C, Foti D. Type 2 Diabetes Melitus and Cardiovascular Disease: Genetic and Epigenetic Links. Front Endrocinol. 2018;9:2-8.

13. Zitnanova I, et al. Gender differences in LDL and HDL cholesterol subfractions in patients after the acute ischemic stroke and their association with oxidative stress markers. J Clin Biochem Nutr. 2018;63(2):144-48.

14. Gupta R, et al. Gender differences in 7 years trends in cholesterol lipoproteins and lipids in India: Insights from a hospital database. Indian J Endocrinol Metab. 2016; 20(2):211-8.

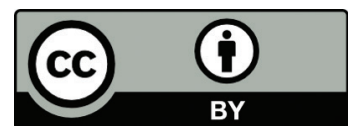

This work is licensed under a Creative Commons Attribution 